\title{
Mobile Collaboration for Young Children
}

\author{
Jerry Alan Fails \\ Human-Computer Interaction Lab \\ Computer Science Department \\ University of Maryland \\ College Park, MD 20742 USA \\ fails@cs.umd.edu
}

\begin{abstract}
Social interaction and collaboration are essential to the emotional and cognitive development of young children [40]. Constructionism [32] is a learning theory where children learn as they build or construct a public artifact. Creative activities that promote collaboration, especially those based on principles of constructionism, provide enhanced learning opportunities for young children. Mobile devices can support the learning experience as children can create artifacts in various contexts. The proposed research incorporates collaboration, constructionism, children, stories and mobile technologies; specifically investigating developmentally appropriate interfaces to support mobile collaboration for young children.
\end{abstract}

\section{Author Keywords}

Children, mobile devices and computing, collaboration, narrative systems, constructionism, stories, user interfaces

\section{ACM Classification Keywords}

H.5.3 [Group and Organization Interfaces]: Collaborative computing; H.5.2 [User Interfaces]: Interaction styles, prototyping, user-centered design.

\section{INTRODUCTION}

As the American flag waves above Fort McHenry (a $19^{\text {th }}$ century battleground and birthplace of the U.S. National Anthem), children explore the fort carrying mobile devices (personal digital assistants, PDAs) collecting, creating, collaborating and learning about the structure, events and people associated with this historic site. These children are creating a shared story describing their collective experience as they visit the fort. One child reads out loud and records on his mobile device a placard describing the magazine. Another child adds to the narrative by writing "this is a historic place" as he walks around the inner fort. Two children walk through an exhibit illustrating life as a

Permission to make digital or hard copies of all or part of this work for personal or classroom use is granted without fee provided that copies are not made or distributed for profit or commercial advantage and that copies bear this notice and the full citation on the first page. To copy otherwise, to republish, to post on servers or to redistribute to lists, requires prior specific permission and/or a fee.

IDC '07, June 6-8, 2007 Aalborg, Denmark

Copyright 2007 ACM 978-1-59593-747-6/07/0006... \$5.00 soldier and capture the audio being narrated as they walk from one room to the next. Another child begins to write out the national anthem as he adds a picture of a flag to an instrumental arrangement of the national anthem as he stands by a cannon overlooking the bay with the flag waving behind him. Children come together sharing and discussing what they have added, even though all can see the additions and changes each other has made.

This describes some of the interactions that occurred during an initial investigation into the use of mobile devices as collaborative tools to construct narratives in context. This research proposal will leverage the lessons learned from these active, playful learning experiences to develop and evaluate new mobile technologies for children, ages 6-10. Specifically, software architectures will be developed and physical interactions will be evaluated to better understand collaboration between children with mobile devices. True mobility not only increases access to the available information, but can allow content creation when and where a user is inspired. Mobile devices empower children to create content or digital artifacts in situ, while they are in the context of the object or situation for which they are creating a representation $[15,25]$. Creative, constructive, and generative activities in context are extremely educational as they help the learner synthesize the information as well as provoke further investigation.

In the last two decades, mobile devices (e.g. cell phones, PDAs, etc.) have become more and more popular and ubiquitous [4]. In fact, it is anticipated that within the next three years, more than 2.6 billion mobile devices will be in use throughout the world $[4,8,24,42]$. This proliferation is significant. If these devices were equally distributed among the population of the earth, approximately $40 \%$ of the world's population would have access to a mobile device [8]. In several places, mobile phones instead of landline phones have become the norm [3]. In developing countries, even those with struggling economies, cell phones have empowered users enabling opportunities not previously attainable $[1,39]$. Indeed, mobile technologies are emerging as the computing platform of the $21^{\text {st }}$ century [11].

Besides being used for telephone communication, mobile devices have been used for consumption, collection, and 
controlling. Consumption generally takes the form of music, video, words, games, or receiving alerts. In some cases, content has been authored specifically for mobile phones including novels [5] and video [6]. Mobile devices such as PDAs (Personal Digital Assistants) have been used for collecting brief text or audio notes [23, 38] as well as more recently, cell phones for pictures and video [7, 12, 13]. Projects have been developed to enable mobile devices as a personal universal controller (PUC) that controls everything from a Microsoft PowerPoint presentation to a VCR [28, 29]. Mobile device usage as a control or input device has also been proposed in many multi-modal systems where multiple devices can be used in partnership (e.g. a PDA controls a TV, which could enable voice tagging of comments about a particular document) $[16,28$, 30].

While past mobile devices have been geared towards consumption, collection and controlling, the research proposed herein represents a shift to enable creative, constructive and collaborative use of mobile devices. Although generating content has been allowed on mobile devices (e.g. text and audio notes), there are interactive limitations to these relatively small devices [37]. The proposed research looks at ways to overcome these limitations via co-present collaboration. Co-present collaboration occurs when people meet at the same time and place to "work together, especially in a joint intellectual effort" [2]. This research proposes not only bringing people together in the same place but specifically investigating how bringing mobile devices together can afford different collaborative advantages for young children.

Moving beyond consumption enables interactive learning, allowing creation of artifacts, thus enabling constructionistic learning [32]. Generative processes go beyond recall and recognition learning and suggest a deeper understanding [33]. This adheres to Papert's learning theory of constructionism which is based on manipulating objects and building a public artifact - it is in the construction of the artifact that children learn [9, 31, 32]. This principle has been used to develop several systems including Logo where children explore the world of math by controlling a turtle graphics object via a simplified programming language [31] and $L E G O / \operatorname{Logo}$ and the $L E G O{ }^{\circledR}$ Bricks which provided more direct physical manipulation allowing children to touch, move and program physical creations $[34,35]$. Constructionism applies to the target age range of this study (6-10 years old), but is not only applicable to the young children, but also on up to middle school aged children) [9, 31, 32].

Narrative systems have started to address issues of mobility by using ubiquitous and tangible computing technologies. Ubiquitous computing technologies are technologies that are embedded and integrated into the environment [41]. They generally use sensing of some sort to enable user interaction [18]. This type of technology has been used in mobile field trip environments to encourage collection of data $[23,36]$. Graspable or tangible computing involves physical manipulation of objects such as coupling a digital document to a physical brick or a triangle and modifying the virtual by physically manipulating the physical $[19,20$, 22]. This technology has been used in narrative systems to enable programming or configuring stories $[10,21,22,26$, 27]. Instead of embedding technology into the environment or using tangible props, the proposed work equips children with mobile devices to enable true mobility.

By expanding the functionality of mobile phones from being used for communication, consumption, collecting and controlling to creative, constructive and collaborative processes, I will enable children to leverage the power of mobile devices for constructive learning. Mobile story authoring and sharing including co-present collaboration can yield social, interactive, exploratory, creative, constructive, mobile play and learning opportunities. With the added computing potential promised to future mobile devices, corresponding advances in the types of interactions and collaboration are necessary to overcome the various limitations and challenges attributed to mobile devices. Copresent mobile collaboration, the focus of the proposed research, addresses many of these important issues.

The proposed research will enable children to collaboratively construct narratives in mobile settings. Specific attention is given to co-present collaboration in mobile situations. By emphasizing the ability to create and author narratives, many educational opportunities are opened; the ability to create and author content in general is uncommon on mobile devices.

\section{RESEARCH QUESTIONS}

The following research questions will be examined through the development of a system for mobile collaboration between children. This system, Mobile Stories, will have a flexible architecture that enables structured, semistructured, and unstructured narrative activities along with support for varying degrees of collaboration. A variety of evaluation methods will be used to investigate how a continuum of activities ranging from reading, watching or playing a narrative to an open generative process could be made available in a collaborative, mobile setting.

\section{What are the appropriate interfaces for co-present mobile collaboration with children?}

To address this question I will develop a platform to enable collaborative tiling and sharing of screen space as well as delivering disparate synchronized information (see Figure 1). Allowing devices to come together can ameliorate the problem of limited screen space. The fact that there are two devices also increases the interactive possibilities. The designed system architecture must not only handle sharing of screen space, but also allow sharing of interactions made on each device to leverage the new, joint interactive opportunities. Devices could physically snap together, or at a minimum be brought in close proximity to be collaboratively connected. 


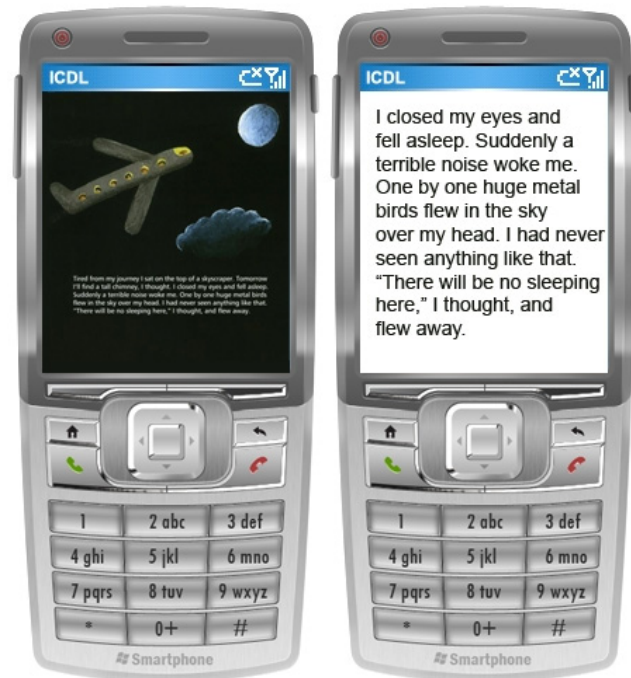

Figure1 - Mobile collaboration mockups using Ciconia Ciconia (White Stork) by Andrea Petrlik published 2003, Kašmir Promet Croatia, Available in the International Children's Digital Library (ICDL)

This co-present workspace expansion within the mobile context however has not been widely explored or commercially leveraged. Bringing devices together can go beyond merely adding pixels to the interface, but can enable novel interactions which can encourage and foster collaboration.

\begin{abstract}
What are the appropriate interfaces for switching between the different modes of collaboration and varying levels of creation/consumption?

I will develop "cognitively light" interfaces to enable children to switch between different modes of collaboration. Collaborative modes include co-present (same place) and distributed (different places) as well as synchronous (same time) and asynchronous (different times). Further discussion of collaborative categorizations and modes is in Section 2.2. I will use qualitative and quantitative evaluation methods to understand what interface technologies (e.g., physical switches, virtual onscreen interactions, or passive, sensing techniques) are appropriate for co-present, collaborative situations. The continuum from construction to consumption will be used as varying contexts with which to test these interface technologies with children.
\end{abstract}

How do collaborative mobile technologies affect children's collaboration?

This question will explore to what extent the developed technologies aid, promote and/or encourage collaboration. This will be investigated via a study with child users in an active context similar to Fort McHenry National Park where my formative study was done. The technology will be instrumented so as to keep logs of all user interactions including creating, editing and collaboration. Researchers will note observations to corroborate data found through the technology.

\section{EXPECTED CONTRIBUTIONS}

The major contributions of this work will be the design and development of a platform and interfaces supporting copresent mobile collaboration, a child-appropriate, light interface for switching between other collaborative modes, and an evaluation examining these developments.

\section{WORK DONE TO DATE}

Initial investigations included a comparison between desktop and physical interactive environments [17] providing direction towards mobile computing environments that can bridge the virtual-physical gap. Preliminary design sessions on collections were performed with children. Observations were made leading the direction from direct support for collections (collecting, organizing, sharing), to a narrative approach which inherently supports these activities. These sessions along with collaborating work with Tangible Flags [14] helped form the direction for this research.

An initial prototype for Mobile Stories was built and tested with children at Fort McHenry National Park. The prototype supported the addition and editing of multimedia to scenes in a shared narrative. The supported multimedia included sound, pictures, and words. The opening situation is a description of some of the interactions observed. Observations from this initial study have formed the ideas for this proposed work.

\section{REFERENCES}

1. Cell phones play vital role in developing world, Associated Press, Hanoi, Vietnam, 2007, http://www.cnn.com/2007/ TECH/ptech/2001/2029/cell.phone.revolution.ap/index.html.

2. Collaboration. in Dictionary.com ed. The American Heritage ${ }^{\circledR}$ Dictionary of the English Language, Fourth Edition, Houghton Mifflin Company, 2004, http://dictionary.reference. $\mathrm{com} /$ browse/collaboration.

3. Emerging markets pushing cell-phone growth, United Press International, 2005, http://www.physorg.com/news5335.html.

4. Gartner Says Mobile Phone Sales Will Exceed One Billion in 2009 Press Release, 2005, http://www.gartner.com/ press_releases/asset_132473_132411.html.

5. Re: book written in txt msg, CNN.com, Helsinki, Finland, 2007, http://www.cnn.com/2007/TECH/ptech/2001/2025/ sms.novel.ap/index.html.

6. The really small screen - cell phone movies, Associated Press, Boston, Massachussetts, 2006, http://www.cnn.com/2006/ TECH/ptech/2010/2030/making.mobilettes.ap/index.html.

7. WITNESS, www.witness.org.

8. World POPClock Projection, U.S. Census Bureau, http://www.census.gov/ipc/www/popclockworld.html.

9. Ackerman, E. Piaget's constructivism, Papert's constructionism: what's the difference?, 2001, $\mathrm{http}$ ///learning.media.mit.edu/content/publications/EA.Piaget $\% 20 \_\% 20$ Papert.pdf.

10. Alborzi, H., Druin, A., Montemayor, J., Platner, M., Porteous, J., Sherman, L., Boltman, A., Taxén, G., Best, J., Hammer, J., Kruskal, A., Lal, A., Schwenn, T.P., Sumida, L., Wagner, R. and Hendler, J. Designing StoryRooms: interactive storytelling spaces for children Conference on Designing Interactive Systems (DIS), ACM Press, New York City, New York, 2000, 95-104. 
11. Barton, J.J., Shumin, Z. and Cousins, S.B. Mobile phones will become the primary personal computing devices Workshop on Mobile Computing Systems \& Applications (WMCSA), IEEE, 2006, 3-9.

12. Cave, D. Must haves: cellphones top Iraqi cool list The New York Times, Baghdad, Iraq, 2006, http://travel.nytimes.com/ 2006/2008/2008/world/middleeast/2008cellphone.html.

13. Cave, D. The reach of war: cellphones in Iraq The New York Times, The New York Times, 2006, http:/www.nytimes.com/ packages/khtml/2006/2008/2007/world/20060807_CELLVID EO FEATURE.html.

14. Chipman, G. Tangible flags: a framework to support the collaborative construction of knowledge artifacts by young children exploring real world environments, University of Maryland, 2005.

15. Chipman, G., Druin, A., Beer, D., Fails, J.A., Guha, M.L. and Simms, S. A case study of tangible flags: a collaborative technology to enhance field trips Proceeding of the 2006 conference on Interaction design and children, ACM Press, Tampere, Finland, 2006.

16. Coles, A., Deliot, E., Melamed, T. and Lansard, K. A framework for coordinated multi-modal browsing with multiple clients International Conference on the World Wide $W e b(W W W)$, ACM Press, Budapest, Hungary, 2003, 718 726.

17. Fails, J.A., Druin, A., Guha, M.L., Chipman, G., Simms, S. and Churaman, W. Child's play: A comparison of desktop and physical interactive environments Proceeding of the 2005 conference on Interaction design and children, ACM Press, Boulder, Colorado, 2005.

18. Fails, J.A. and Olsen, D.R. Light widgets: interacting in everyday spaces Proceedings of the 7th international conference on Intelligent user interfaces, ACM Press, San Francisco, California, USA, 2002.

19. Fitzmaurice, G.W. Graspable user interfaces Department of Computer Science, University of Toronto, 1996.

20. Fitzmaurice, G.W., Ishii, H. and Buxton, W.A.S. Bricks: laying the foundations for graspable user interfaces Conference on Human Factors in Computing Systems (CHI), ACM Press/Addison-Wesley Publishing Co., Denver, Colorado, United States, 1995, 442-449.

21. Gorbet, M.G. Beyond input devices: a new conceptual framework for the design of physical-digital objects School of Architecture and Planning, Massachusetts Institute of Technology, Boston, 1998, 111.

22. Gorbet, M.G., Orth, M. and Ishii, H. Triangles: tangible interface for manipulation and exploration of digital information topography Conference on Human Factors in Computing Systems (CHI), ACM Press/Addison-Wesley Publishing Co., Los Angeles, California, United States, 1998, 49-56.

23. Halloran, J., Hornecker, E., Fitzpatrick, G., Weal, M., Millard, D., Michaelides, D., Cruickshank, D. and De Roure, D., The literacy fieldtrip: using UbiComp to support children's creative writing. in Proceeding of the 2006 conference on Interaction design and children, (Tampere, Finland, 2006), ACM Press, 17-24.

24. Hirst, C. Forecast: Mobile Phone Memory Consumption, Worldwide, 2005-2010 (3Q06 Update), Gartner Inc., 2006.

25. Hundebøl, J. and Helms, N.H. Pervasive e-learning - In situ learning in changing contexts DREAM 2006 Conference on
Informal Learning and Digital Media, Odense, Denmark, 2006.

26. Montemayor, J., Druin, A., Chipman, G., Farber, A. and Guha, M.L. Tools for children to create physical interactive storyrooms. Computers in Entertainment (CIE), 2 (1). 12-35.

27. Montemayor, J., Druin, A., Farber, A., Simms, S., Churaman, W. and D'Amour, A. Physical programming: designing tools for children to create physical interactive environments Conference on Human Factors in Computing Systems (CHI), ACM Press, Minneapolis, Minnesota, 2002, 299-306.

28. Myers, B.A., Nichols, J., Wobbrock, J.O. and Miller, R.C. Taking handheld devices to the next level. Computer, 37 (12). 36-43.

29. Myers, B.A., Stiel, H. and Gargiulo, R. Collaboration using multiple PDAs connected to a PC Proceedings of the 1998 ACM conference on Computer supported cooperative work, ACM Press, Seattle, Washington, United States, 1998.

30. Olsen, D.R., Jefferies, S., Nielsen, T., Moyes, W. and Fredrickson, P. Cross-modal interaction using XWeb $A C M$ symposium on User Interface Software and Technology (UIST), ACM Press, San Diego, California, 2000, 191-200.

31. Papert, S. Mindstorms: children, computers, and powerful ideas. Basic Books, New York, 1980.

32. Papert, S. and Harel, I. Constructionism: research reports and essays, 1985-1990. Ablex Publishing Corporation, Norwood, New Jersey, 1991.

33. Piaget, J. To understand is to invent: The future of education. Grossman, New York, 1973.

34. Resnick, M., Martin, F., Sargent, R. and Silverman, B. Programmable bricks: toys to think with. IBM Systems Journal, 35 (3-4). 443-452.

35. Resnick, M. and Ocko, S. LEGO/Logo: learning through and about design. in Harel, I. and Papert, S. eds. Constructionism, Ablex Publishing, Norwood, New Jersey, 1991.

36. Rogers, Y., Price, S., Fitzpatrick, G., Fleck, R., Harris, E., Smith, H., Randell, C., Muller, H., O'Malley, C., Stanton, D., Thompson, M. and Weal, M., Ambient wood: designing new forms of digital augmentation for learning outdoors. in Proceeding of the 2004 conference on Interaction design and children: building a community, (Maryland, 2004), ACM Press, 3-10.

37. Shudong, W. and Higgins, M. Limitations of mobile phone learning IEEE International Workshop on Wireless and Mobile Technologies in Education (WMTE), IEEE Press, The University of Tokushima, Japan, 2005.

38. Su, N.M., Sakane, Y., Tsukamoto, M. and Nishio, S. Rajicon: remote PC GUI operations via constricted mobile interfaces International Conference on Mobile Computing and Networking (MOBICOM), ACM Press, Atlanta, Georgia, 2002, 251-262.

39. Sullivan, K. For India's traditional fishermen, cellphones deliver a sea of change Washington Post Foreign Service, Pallipuram, India, 2006, A01.

40. Vygotsky, L.S. Mind in society: the development of higher psychological processes. Harvard University Press, Cambridge, Massachusetts, 1978.

41. Weiser, M. The Computer for the 21st Century Scientific American, 1991, 94-104.

42. Wood, B., Milanesi, C., Liang, A., De La Vergne, H.J., Nguyen, T.H. and Mitsuyama, N. Forecast: Mobile Terminals, Worldwide, 2000-2009, Gartner Inc., 2005. 